INTERNATIONAL JOURNAL FOR

HISTORY, CULTURE AND MODERNITY

www.history-culture-modernity.org

Published by: Uopen Journals

Copyright: @ The Author(s).

Content is licensed under a Creative Commons Attribution 4.0 International Licence

elSSN: 2213-0624

\title{
Advancing American Art and Intercultural Confrontations in Germany, 1945-1948
}

\author{
Frank Mehring
}

HCM 7: 971-990

DOI: $10.18352 / \mathrm{hcm} .594$

\begin{abstract}
This article critically addresses the multivalent function of American art exhibitions in the period of de-Nazification and re-democratization. What kind of cultural and political parameters shaped the perception of American Art in Germany during the early post-war years? I investigate intercultural confrontations surrounding the project of advancing American art and the critical response of German audiences by first looking at the exhibition Advancing American Art from I947. I then analyze the role of the transatlantic cultural mediator Hilla von Rebay to understand developments in the German perspective on American art. The German-born artist von Rebay emigrated in 1927 to the United States and organized the German tour of Zeitgenössische Kunst und Kunstpflege in U.S.A. (Contemporary Art and the Promotion of Arts in the U.S.A.) authorized by the Office of Military Government, United States (OMGUS) in I948. The project of 'advancing American art' resembles a struggle with many setbacks due to lack of official support and finding a larger public in the early years after World War II.
\end{abstract}

Keywords: abstract expressionism, American art, cultural diplomacy, democratization, Germany, non-objective art 


\section{Introduction}

As Aleida Assmann explains, 'individuals and cultures construct their memories interactively through communication by speech, images, and rituals'. ${ }^{I}$ Art has been at the centre of German national self-perception shaping aesthetic conceptions of the country's past and future, particularly after the ominous 'hour zero' and the beginning of the so-called 'American century'. Today, art continues to inform the discourse of national identity constructions, albeit within larger transnational frameworks, as two recent large-scale exhibitions devoted to remapping Art in Europe suggest: Facing the Future: Art in Europe 1945-1968 (Karlsruhe, 22 October 2016-29 January 2017) and Postwar: Art Between the Pacific and the Atlantic, 1945-1965 (Munich, I4 October 20I6-26 March 2017). Both exhibitions put particular emphasis on multi-perspectivity. The pan-European perspective offers a 'unique opportunity to investigate a new interpretation of the development of art in Europe', as the organizers claim. ${ }^{2}$ This approach moves beyond the fixation on the Cold War narrative of the triumph of Abstract Expressionism symbolizing freedom of the West over Soviet Social Realism with its connotations of ideologically streamlined art in the communist East. ${ }^{3}$ With their focus on presenting a kaleidoscope of innovative artistic productions all across Europe, both exhibitions, however, run the risk of losing sight of the circulation of images that informed state sponsored exhibitions which visualized a democratic narrative of post-war Europe, particularly in West Germany.

I am interested in exploring the liminal space between Hitler's denouncement of Futurism, Cubism and Dadaism as 'insane and inane monstrosities' ${ }^{4}$ and the emerging prominence of American contemporary art after World War II in West Germany. The connection between art and politics is not only part of what Walter Benjamin identified as the aestheticization of politics but also the politicization of art. ${ }^{5}$ After World War II, the aesthetization of democracy became a major issue in the U.S. effort to counterbalance political agendas of the National Socialist past and in the growing political polarization during the Cold War. ${ }^{6}$ With an eye towards the re-education and re-democratization programmes, the dynamic intercultural exchange and confrontations in U.S. Government sponsored art exhibits and the reception of American art in public discourse might offer valuable clues to answer the question: 
What kind of cultural and political parameters shaped the perception of American Art in post-war Germany before the Americanization efforts of the Marshall Plan became effective?

To answer this question, I will trace U.S.-German encounters during the first years after the proverbial 'hour zero', paying special attention to three exhibitions. I will investigate moments of intercultural confrontations by first looking at the concept of travelling exhibitions such as Advancing American Art from 1947 and the critical responses that contributed to its failure. In a second step, I will analyze the role of the transatlantic cultural mediator Hilla von Rebay (I890-I967) to explore developments in the German perspective on American art. The German-born artist Hilla von Rebay, born the Baroness Hildegard Anna Augusta Elisabeth Rebay von Ehrenwiesen in Strassburg, emigrated to New York in $1927 .{ }^{7}$ Among other events, she organized the German tour of Zeitgenössische Kunst und Kunstpflege in U.S.A. (Contemporary Art and the Promotion of Arts in the U.S.A.) authorized by the Office of Military Government, United States (OMGUS) in I948.

\section{Winning the Hearts and Minds of Post-War Germans}

The reception of American Art in Germany has been particularly influenced by two forces which are located outside the field of artistic creativity. First, the political censorship and concerted propaganda efforts of National Socialism culminating in the 1937 exhibition Entartete Kunst (Degenerate Art) in Munich. Second, the re-orientation and re-education of West Germany by the American occupation forces. After the end of World War II, the U.S. State Department activated all channels of media communication to redirect the hearts and minds of Germans towards embracing the American model of democracy as well as the American way of life. ${ }^{8}$ Historian David Ellwood has described these efforts as 'the greatest propaganda coup ever launched during times of peace'. 9 Among the seventeen receiving countries of Marshall Plan aid, Germany represents, as Alexander Stefan claims, a 'special case' of cultural Americanization. ${ }^{10}$ While this word smacks of propaganda and monocausal notions of cultural imperialism, European cultural critics such as Reinhold Wagnleitner, Rob Kroes and Winfried Fluck have pointed towards processes of cultural appropriation and ultimately cases of self-Americanization. ${ }^{11}$ 
During the last decades, scholars of cultural diplomacy have focused on what Josef Nye describes as soft power. Nye referred to products and practices of American culture that can generate positive attraction, be persuasive and create new venues for American culture overseas. ${ }^{12}$ Historians and experts in media studies such as Rainer Rother, Gabriele Clemens, Victoria de Grazia and David Ellwood have addressed the function of American film and consumer culture in the process of democratizing Germany after World War II. ${ }^{13}$ Others such as Penny van Eschen, Jessica Gienow Hecht, Gerhard Paul and Ralph Schock have explored the function of music as a cultural ambassador. ${ }^{14}$

With few exceptions such as Catherine Dossin's comprehensive overview The Rise and Fall of American Art, I940s-I980s and Cora Sol Goldstein's Capturing the German Eye, the function of art in intercultural encounters and cultural diplomacy in Germany during the first years after World War II has been hardly addressed. ${ }^{15}$ Other publications such as Cold War on the Home Front by Greg Castillo or Cultural Diplomacy and the Cold War by Naima Prevots focus on American design and dance, the challenges of using the medium of art in the immediate years after World War II remains on the fringes. ${ }^{16}$ One of the most comprehensive and elaborate investigations of art exhibitions is Jack Masey's and Conway Lloyd Morgan's monumental book on Cold War Confrontations. However, their critical overview begins in I 948 with travelling caravans organized under the auspices of the Marshall Plan. These exhibitions did not rely on the display of art but rather the medium of film, photographs, text and charts. ${ }^{17}$ Other publications such as Images of the Marshall Plan in Europe edited by Günter Bischof and Dieter Stiefel investigate similar media while the function of art is not mentioned. ${ }^{18}$

To understand the function of art in German-American intercultural confrontations, we need to first critically evaluate developments in U.S. and German national art scenes. International writers and critics have already started to question the familiar story of 'The Triumph of American Painting' by focusing on art criticism. ${ }^{19}$ This story situates the exceptionalist American development in Depression-era social realism with its driving forces in the context of World War II, the cross-fertilizations through avant-garde artists fleeing Europe, via expressive action painting and post-Cubist abstraction at a distinctively American art tradition..$^{20}$

As the German art historian Hans Belting explained, the theme of German Art was a taboo during the first decade after WWII among 
German art historians due to the fact that it had been exploited for ideological purposes from I933-I945. ${ }^{2 \mathrm{I}}$ The fragile construction of a German identity was problematic in many ways. First, due to the separation of Germany into ideological sections east and west, the two national entities lost a substantial part of their creative substance. It rendered a notion of art in terms of geographical location obsolete. Second, German scholars substituted notions of a German art with a wider, more integral term: abendländische Kunst (art of the Occident). During the phase known as 'de-Nazification' under the auspices of the American occupiers, the Haus der Deutschen Kunst dropped its national signifier to rehabilitate itself as the Haus der Kunst, embracing a more international agenda. ${ }^{22}$ As Belting made clear, one rather asked, "what is art rather than what is German art. In this investigation, art epochs were more important than national contributions'. ${ }^{23}$

At the moment of defeat and liberation, the encounter of the American forces with German art is marked by a combination of disrespect and the ritual of iconoclasm. Okwui Enwezor, curator of the recent large-scale exhibition Postwar Art: Between the Pacific and the Atlantic 1945-1965 (2016-2017), ${ }^{24}$ points to the unusual American self-inscription in German art history at the Haus der Deutschen Kunst, one of the National Socialist Centres of art exhibitions. The title page of the Goldenes Buch signed by Adolf Hitler shows additional signatures of three American soldiers from 5 May I945. These signatures of American citizens in uniforms have a special significance at the very place where Nazis connected notions of 'degenerate art' with Jewishness and, among other things, American jazz..$^{25}$ The self-inscription marks the ideological shift from a tyrannical control of art to a democratic use of art American style. The function of art in cultural diplomacy to foster mutual understanding, dialogue and cooperation proved to be problematic, however. As a matter of fact, the combination became 'controversial' as soon as the Office of Information and Cultural Affairs was turning to the field of art. ${ }^{26}$

The German born Hellmut Lehmann-Haupt played a decisive role in propagating art as a means of cultural diplomacy. As a former specialist in fine arts in Weimar Germany, he moved to the U.S. in I929 and returned to Berlin as an officer within the section of the Office of Military Government US (OMGUS) that was dedicated to Monuments, Fine Arts and Archives (MFA\&A). In February I947, Lehmann-Haupt 
emphasized the political importance of art and the need for the U.S. to include it in their 'cultural reorientation' programme:

German museum and art life is not [my emphasis], as it may seem at first sight, a neutral field, devoid of political implications. On the contrary it is an active and vital factor capable of exerting considerable influence on public opinion and in formulating emotional and psychological attitudes. It must therefore be considered an important educational factor and, at least to some degree, a medium of public information. The authority and prestige which all manifestations of cultural life enjoy in the German community is very considerable. It is therefore necessary to realize that the activities of museums and other cultural and artistic organizations in Germany have a much greater influence, compared with other manifestations of public life, than in the United States or Great Britain. ${ }^{27}$

In 1947 it was not clear how art could function as a means for cultural re-orientation. On I 2 November 1947, Captain Edith Appleton Standen, the director of the MFA\&A art collecting point at Wiesbaden, complained that the situation at the ICD, the Information Control Division of OMGUS, is 'ridiculous' ${ }^{28}$ The goal should be to re-establish museums and galleries, art exhibitions, lectures, arrange for travel of German art personnel, export modern art and related undertakings to establish international cultural relations. ${ }^{29}$ On a practical level, Standen wanted to promote and sponsor exhibitions of American and German art, organize lectures by American art scholars in Germany and facilitate the export of modern German art. However, for a long time, museums and fine arts resembled a kind of blind spot in cultural diplomacy. By that time, the project of promoting American art abroad was already seen a great failure. The complications and disagreements over the travelling exhibition Advancing of American Art is a revealing case in point regarding the slow and delayed embrace of fine arts as an means of cultural diplomacy.

\section{Advancing American Art (1947)}

With the inauguration of the Fulbright Act in I 946 to foster international exchange and the State Department's conviction that the United States 
should take the lead in cultural matters to assume cultural hegemony in central Europe, assistant secretary of state William Benton suggested a worldwide art programme to publicize American works in fine arts. During the Cold War, art exhibitions were supposed to spread positive messages about U.S. American artistic accomplishments and counterbalance conceptions of the country as being an 'artistic backwater'. $3^{3}$ In collaboration with J. Leroy Davidson, the former curator of the Walker Art Center in Minneapolis, the idea was developed to organize an exhibition of modern American paintings and drawings under the title Advancing American Art. The exhibit would tour Europe and South America under government sponsorship. The collection of seventy-one oil paintings and seventy-three watercolours by forty-five American artists consisted of well-known artists such as Stuart Davis, John Marin, Georgia O'Keefe, Ban Shahn, Ben Zion and George Grosz. ${ }^{31}$ It is crucial to recognize that none of the iconic paintings were featured which later would form the reputation of New York as a hub of avant-garde paintings: the New York school of Abstract Expressionism. Still, the selection caused a highly controversial political debate.

The first show at the Metropolitan Museum of Art became the butt of vicious attacks. The New York Journal-American called it "not American at all'. ${ }^{32}$ Rather, the paintings would suggest that the U.S. was a 'drab, ugly place, filled with drab ugly people'. ${ }^{33}$ With a reference to leftist agendas, the entire show was supposedly rooted 'in the alien cultures, ideas, and sickness of Europe' ${ }^{34}$ Marilyn Robb in Art News quoted President Truman on seeing Yasuo Kuniyoshi's Circus Girl Resting (I925): 'If that's art I' $m$ a Hottentot'. ${ }^{35}$ It is interesting that the vocabulary used has uncanny similarities to the defamation of modernist art exhibited in the Degenerate Art show in Munich in 1937. A member of the Republican-dominated Congress explained that the show promoted a distorted, contorted and deformed image of American society. Instead of a strong, healthy nation, George Dondero, Republican senator from Michigan, claimed that the exhibition was

communistic because it is distorted and ugly, because it does not glorify our beautiful country, our cheerful and smiling people, and our great material progress. Art which does not portray our beautiful country in plain, simple terms that everyone can understand breeds dissatisfaction. It is therefore opposed to our government, and those who create and promote it are our enemies. ${ }^{36}$ 
Others such as the representative Fred Busbey from Illinois called it a 'disgrace to the United States', asking 'what kind of crackpots assembled such a jumble of paintings?' ${ }^{77}$ On I 8 February I947, the national magazine Look featured an illustrated article called 'Your Money Bought These Paintings' which implied in inflammatory words that Advancing American Art a negative portrayal of the American nation. ${ }^{38}$ Despite enthusiastic reactions abroad when the show opened in Prague and Havana in early I947, the State Department was instructed to cancel the show due to the mounting pressure and public uproar. ${ }^{39}$ All of the artists involved in the show were later investigated by the House Un-American Activities Committee. With this kind of political censorship and harassment of modernist artists, it would become difficult to denounce the Soviet Union for doing exactly the same in their occupation zone and later in the politically divided Germany. For the time being, the direct intervention of the U.S. Congress in cultural matters seriously complicated and delayed the promotion of American art in Germany and elsewhere in Europe. Due to the failure of Advancing American Art, the American military government began to doubt the potential of fine arts as a means to re-orient and re-educate the former enemies from an elitist nationalist conception of art to a clearer understanding regarding how democratic environments foster new forms of artistic expression. In turn, intellectuals from both sides of the Atlantic sought out new channels of communication to stimulate a resurgence of modern art in Germany. ${ }^{40}$ Within this atmosphere, former German émigrés re-engaged as mediators of artistic exchange and the circulation of art. In the following years, the controversy over and failure of Advancing of American Art overshadowed the function of art as a means of cultural diplomacy.

\section{Hilla von Rebay's Zeitgenössische Kunst und Kunstpflege in U.S.A. (1948)}

The work of Hilla von Rebay, who had emigrated to the U.S. in I927 and became an intimate friend of the American art collector and business man Solomon Guggenheim, offers an interesting perspective on the project of advancing American art and the struggles of cultural diplomacy. Rebay, an artist in her own right and admirer of Wassily 
Kandinsky, had founded the gallery 'Museum of Non-objective Painting' and urged Guggenheim to build a new museum for this collection. She tried to create new opportunities for those artists who had to flee Germany, due to the anti-modernist pressures of the Nazis, to exhibit their work in their former home country. In April I948, she was able to independently collaborate with OMGUS, which authorized her travelling exhibition Zeitgenössische Kunst und Kunstpflege in U.S.A. (Contemporary Art and the Promotion of Art in the U.S.A.). Since the show was made possible for the most part with private funding, the aesthetic control of the U.S. Congress was circumvented in the initial stage. Otherwise, the exhibition might have caused a similar flaming discussion such as the one surrounding Advancing of American Art.

Rebay was interested in fostering abstract art in Germany. She established ties with painters and art dealers in Berlin (such as Lotte Konnerth, Gerd Rosen, Wolfgang Frankenstein) and became an important intercultural mediator in the process of reviving developments in modern art in Germany. ${ }^{41}$ Rebay's exhibition represents the first show of American abstract paintings in Germany. ${ }^{42}$ In Germany, the show opened in the Staatliche Kunsthalle in Karlsruhe thanks to her contacts to her second cousin Kurt Martin who, during the Weimar Republic, was the director of the museum and was working for the Monuments, Fine Arts and Archives Section, OMGUS. ${ }^{43}$ The show then travelled to Munich, Stuttgart, Mannheim, Frankfurt, Düsseldorf, Braunschweig, Hannover and Hamburg.

Among the paintings Rebay selected were not so much the famous ones by Wassily Kandinsky, Paul Klee or Marc Chagall but rather their students and admirers including Rudolf Bauer, Ilya Boltowsky, MoholyNagy, Irene Pereira Rice, Rolph Scarlett and Jean Xceron. Seven of the fifty paintings exhibited in Germany were by herself. In Karlsruhe, the vernissage was coordinated with the re-opening of the Kunsthalle Karlsruhe. Lehmann-Haupt described the show as a "valuable experiment with popular art education'. ${ }^{44}$ The United States Information Center took over the administrative side of the show in I950. Thus, it was possible to mount the show in a number of other German cities.

German audiences responded to this show with mixed feelings. ${ }^{45}$ After all, it featured American artists alongside Europeans who had found an exile in the United States. It became clear that quite a few member of the audience who had been indoctrinated by Nazi 
propaganda regarding allegedly 'degenerated art' with its destructive forces of German taste remained particularly sceptical. A look at reports in the national German magazine Der Spiegel and the newspaper Die Zeit, two influential political weekly publications, offers valuable clues.

The arts section in the Spiegel article from 24 April I 948 consists of two articles. The first one focuses on the loss of prints and paintings of the Kunsthalle Bremen and efforts to purchase works of artists that had been eradicated from the collection during World War II. It is about three times longer than the second report about Hilla von Rebay's exhibition on non-objective art. Comparing both journalistic approaches to the challenges of exhibiting fine arts in Germany is revealing. After citing the losses of precious works such as Madonna by Masccio or Betende Madonna by Montagne, 200 prints and I600 drawings by Dürer, Corinth, van Dyck, Leibl, Liebermann, Menzel, Rafael, Rembrandt, Rubens, Tizian and Veronese, the efforts of the Kunsthalle Bremen to close some of the gaps by new purchases solicits great praise:

Walking through the exhibition of their new paintings was a relief for Bremen citizens. They already knew - even if not to the full extent - that their museum had suffered from losses in the War. They accepted the loss of their precious items with hanseatic stoicism. ${ }^{46}$

Under the title 'Some kind of New York in Karlsruhe' the second report in Der Spiegel focuses non-objective paintings. It starts out by referencing the fact that this was the first American art exhibition in Germany. Right away, the author references the controversial nature of the reception. Non-objective art caused consternation, laughter and 'sometimes also admiration' ${ }^{47}$ In general, the tone of the article resembles, consciously or unconsciously, the rhetoric of American propaganda after World War II. There are subtle references to the then familiar polls organized by the Office of Military Government for Germany (U.S.) to shape German public opinion. Questionnaires helped to observe and report on the direct results of the means of cultural diplomacy and persuasion. A similar point can be made about the final paragraph on the art show in Karlsruhe. "The audience in Karlsruhe rarely said "yes" to non-objective painting. In New York, a museum is being built exclusively for this kind of art - with air conditioning and elevators'. ${ }^{8}$ 
These comments are remarkable for a number of reasons. First, they reveal that the exhibition was not recognized as a privately funded event to re-build bridges to the German art scene which during the Nazi years had cut itself off from the productive art scene in New York from I933 to I945. Rather, references to issues such as awareness, understanding, or approval frames the exhibition implicitly as part of the US American outreach to (re)educate the German audience. In I948, the newspapers reported extensively about the Marshall Plan and what countries would agree to accept Marshall aid within the European Recovery Program. Ultimately, Germany (as well as I6 other countries) said 'yes!' and accepted the American offer, which soon led to heated confrontations with the Soviet Union and ideological escalation of the Cold War. A remarkable sequence from a Marshall Plan documentary film called Ich und Mr. Marshall (I948) indicates the frame of reference. Viewers of this educational film saw an animated map of Europe on which those countries that said 'yes' to Marshall help turned white, while countries in the East who did not want to embrace the America offer of support turned black. The exclamations 'Yes!' and 'No!' appeared in large letters superimposed on the European map.

After I948, there was a 'steady upward trend in awareness of the Marshall Plan' reaching 83\% in the American Zone. ${ }^{49}$ Eighty-five percent believed that the Marshall Plan would increase the German standard of living. Only $25 \%$ believed that the US conceived the Marshall Plan as a means to 'dump goods resulting from overproduction' compared to $44 \%$ understanding the project as a 'sincere desire to help Europe'.$^{50}$ By the second half of I948, only $3 \%$ of the West German people (based on a poll of 3000 cases in the American Zone, 500 in West Berlin and 300 in Bremen) disapproved of the Marshall Plan. ${ }^{51}$ Considering the popular visual narratives of advertising the European Recovery Program, it was difficult to separate public opinion from the notion that any form of cultural transfer was related to US efforts to re re-educate, re-orient, re-democratize, and establish a cultural hegemony. ${ }^{52}$

Second, the final part of the quote on the art show in Karlsruhe refers to the American museum dedicated to the display 'Non-Objective Art'. This museum would later be called the Solomon R. Guggenheim Museum in New York (much to the dismay of Rebay who preferred the title 'Museum of Non-Objective Painting' ${ }^{53}$ ). Rebay was instrumental in conceiving the museum in the late I930s before it would finally open 
to the public in $1959 .{ }^{54}$ Considering the destruction of German cities and complete lack of any luxury, German readers are led to conclude from references to air conditioning and automatic elevators that in this American museum convenience and atmosphere might actually be more important than the works exhibited. The contrast between the first part of the article, chronicling the loss of artworks in Bremen and the inclusion of air conditioning systems and elevators in New York could not be more startling - or even painful.

Third, the aesthetic layout of the article is telling, in that it supports a critical view on the American art exhibition. In particular, the reproduction of an exemplary image from the exhibit at the end of the article was by Hilla von Rebay, who also is identified as the organizer of the exhibit. The image is contrasted with one of the war losses of the Bremer Kunsthalle, reprinted on the upper left corner. Thus, we see Albrecht Dürer's famous figurative watercolour 'Felsenschloss' (I494) ${ }^{55}$ in opposition to Rebay's abstract painting 'Anregung, Bewegung, Aufschwung'. ${ }^{56}$ Undoubtedly, this image was selected not only for its non-objective quality but also for its title which captures some of the key themes of the Marshall Plan: inspiration (or persuasion, in the language of the Marshall Plan), activity (or productivity) and upward movement (or economic progress). The Kunsthalle Bremen suffered some the greatest losses due to bombardments in Germany. ${ }^{57}$ The reference to Dürer, the famous painter, printmaker and theorist of the German Renaissance, evokes a sense of loss, sadness and perhaps even nostalgia of a less troubled past. In addition, the layout contrasts one of the earliest and most celebrated examples of German landscape painting with non-objective approaches coming from the United States. Given a rather critical, or even hostile response of those audiences who had been active members of the National Socialist Party,,$^{58}$ one could argue that due to the war the treasure of German art is being replaced by art exhibited under the auspices of the United States.

A review of the Karlsruhe exhibition Zeitgenössische Kunst und Kunstpflege in U.S.A. in the weekly newspaper Die Zeit from 8 April I 948 offers a different approach. While the museum is still framed condescendingly as resembling a 'huge parking garage', the critic Egon Vietta offers a more positive reading than the author of Der Spiegel. Vietta emphasized continuities to the Bauhaus era and the return of those aesthetic visions that preceded the Nazi terror regime. He recognizes 
the impulse of man in the age of technology and draws connections to the art of Wassily Kandinsky and Willy Baumeister's ground-breaking work Das Unbekannte in der Kunst (1947, The Unknown in Art). German-American cultural intermediators such as Hilla von Rebay can offer innovative impulses. While the final paragraph suggests that the artistic visions of the future are closely connected to German intellectuals before $1933,{ }^{59}$ the headline leaves no doubt about the country of origin of the exhibition: 'Gegenstandslose Malerei: Eine amerikanische Schau in Karlsruhe' (Non-Objective Art: An American Show in Karlsruhe). ${ }^{60}$

With her dedication to the promotion of 'American art', Rebay created a kind of personal artistic re-education project. ${ }^{61}$ It is worthwhile quoting an unpublished letter from 22 September I950 to the naturalized American citizen Edgar Breitenbach, who worked in Munich as the Museum and Fine Arts officer (I945-1949) and in the American High Commission in Bad Nauheim and Frankfurt between I949-I953, in the Cultural Relations Division, Section for Fine Arts, Museums, Libraries and Archives reconstructing German libraries. Rebay writes: 'Out-dated ideas can hardly be helpful to the great mission we have, which is to bring to America the name of cultural leadership. We see from the many reports we receive internationally that it is acquiring this reputation, very greatly due to our leading work. I am sending you the public comments received during the past two weeks'. ${ }^{62}$ No doubt, Rebay followed a double agenda. She tried to frame her efforts to promote American art within the larger context of re-education. The artworks she selected for the exhibitions relied for the most part on exile artists from the Bauhaus school and others associated with developments to move from figurative to abstract forms of painting, including her own work. In the spirit of OMGUS polls, Rebay included enthusiastic statements of exhibition visitors who praised the experience of non-objective art.

However, Breitenbach finally decided to not support Rebay's art show and canceled 'the already scheduled and prepared exhibits at the America Houses in Hamburg and Bremen' ${ }^{63}$ It was not before I95 I during the Berlin Festival that Germans had the opportunity to see exclusively American art in the show called Amerikanische Malerei: Werden und Gegenwart (American Art: Becoming and Presence) organized by David Finley, director of the National Gallery of Art in Washington, DC. However, the show with works by Thomas Eakins, William 
Merritt Chase, Winslow Homer, Thomas Hart Benton Charles Demuth, Marsden Hartley, Stuart Davis, Edward Hopper, Marc Rothko, Jackson Pollock and others, was seen by only by a few number of Berlin residents and its impact should therefore not be overestimated.

\section{Conclusion}

The project of 'advancing American art' in Germany resembles a struggle with many setbacks due to lack of official support and finding a larger public in the early years after World War II. While U.S. cultural diplomacy embraced almost all forms of cultural expressions to re-educate German citizens in the western allied occupation zones and make persuasive arguments for embracing democratic traditions American style, the fine arts posed particular challenges. Late modernist and abstract developments in the American art scene did not fit the political agenda of fostering a positive image of the U.S. Examples of non-objective art could only cross the Atlantic via non-governmental funding and intercultural mediators such as Hilla von Rebay whose specific transatlantic biography allowed her to draw on international networks.

Within the German cultural context of the first years after World War II, the display of art allowed Germans to re-connect with artistic developments before the National Socialist terror regime drove many German and European artists into the American exile. It would allow future audiences to re-inscribe themselves into a larger European context. ${ }^{64}$ By tracing the struggles of advancing American art in the postwar years in Germany lies a chance to better understand the German efforts to situate art in a specific international and later transnational European perspective.

\section{Notes}

I Aleida Assmann, Cultural Memory and Western Civilization: Functions, Media, Archives (Cambridge, 20 I I) Io.

2 Eckhart Gillen and Peter Weibel, 'Europe after the Rain: The Dialectic of Trauma and Revival in European Art from I945 to I968', Idem (eds), Facing the Future: Art in Europe 1945-1968 (Tielt, 2016) I2-5, at I4. 
3 Ibid., I4.

4 Adolf Hitler, 'Speech Inaugurating the "Great Exhibition of German Art," Munich', in Herschel B. Chipp (ed.), Theories of Modern Art (Berkeley, I968) 476.

5 See Walter Benjamin, 'Theorien des deutschen Faschismus', Gesammelte Schriften Vol. 3. (Frankfurt, I974), 238-50.

6 Walter Grasskamp argued that it is a painful weakness of democracy that art has hardly anything to offer to counterbalance the aesthetic splendour of tyranny; Grasskamp, Die unästhetische Demokratie. Kunst in der Marktgesellschaft (München, I992) 9.

7 Barbara Sicherman and Carol Hurd Green (eds), Notable American Women: The Modern Period. A Biographical Dictionary (Cambridge I980), 57 I.

8 Frances Stonor Saunders has revealed the complex ways in which the CIA secretly intervened in cultural diplomacy efforts after World War II in Who Paid the Piper? The CIA and the Cultural Cold War (Croyden, I999).

9 David Ellwood, 'Film and the Marshall Plan', Guenter Bischof and Dieter Stiefel (eds), Images of the Marshall Plan in Europe. Films, Photographs, Exhibits, Posters (Innsbruck, Wien, Bozen, 2009), 6I-8, at 62.

Io Alexander Stephan, 'A Special German Case of Cultural Americanization', Idem (ed.), The Americanization of Europe. Culture, Diplomacy, and AntiAmericanism after 1945 (New York, Oxford, 2006), 69-90, at 69.

I I Winfried Fluck, Romance with America? Essays on Culture, Literature, and American Studies (Heidelberg, 2009); Rob Kroes and Robert W. Rydell, Buffalo Bill in Bologna: The Americanization of the World, I869I922 (Chicago, 2005); Reinhold Wagnleitner, Coca-colonisation und Kalter Krieg: Die Kulturmission der USA in Österreich nach dem Zweiten Weltkrieg (Wien, I99I).

I 2 Joseph S. Nye, Jr., The Future of Power (New York, 20I I) 90-3.

I3 Cabriele Clemens (ed.), Werben für Europa: Die mediale Konstruktion europäischer Identität durch Europafilme (Paderborn, 20I6); David W. Ellwood, The Shock of America: Europe and the Challenge of the Century (Oxford, 2O I2); Victoria di Grazia, Irresistible Empire: America's Advance Through Twentieth-Century Europe (Cambridge, 2006); Rainer Rother and Judith Prokasky, Die Kamera als Waffe: Propagandabilder des Zweiten Weltkriegs (München, 20I0).

I4 Penny M. von Eschen, Satchmo Blows Up the World: Jazz Ambassadors Play the Cold War (Cambridge, 2006); Jessica C. E. Gienow-Hecht (ed), Music and International History in the Twentieth Century (Oxford, 
20I5); Gerhard Paul and Ralph Schock (eds.), Sound des Jahrhunderts: Geräusche, Töne, Stimmen I889 bis Heute (Bonn, 20I3).

I5 The most informative scholarly work is Cora Sol Goldstein's Capturing the German Eye: American Visual Propaganda in Occupied Germany (Chicago, 2009). A valuable contribution to the revisionist discourse on the covert actions surrounding the export of Abstract Expressionism is offered by Greg Barnisel, Cold War Modernists: Art, Literature, and American Cultural Diplomacy (New York, 2015).

I6 Jack Masey and Conway Lloyd Morgan, Cold War Confrontations: US Exhibitions and Their Role in the Cultural Cold War (Baden, 2008); Greg Castillo, Cold War on the home Front: The Soft Power of Midcentury Design (Minneapolis, 2010); Naima Prevots, Dance for Export: Cultural Diplomacy and the Cold War (Middletown, I998).

I7 Jack Masey and Conway Lloyd Morgan, Cold War Confrontations. US Exhibitions and their Role in the Cultural Cold War (Baden 2008).

I 8 Günter Bischof and Dieter Stiefel (eds), Images oft he Marshall Plan in Europe. Films, Phototgraphs, Exhibits, Posters (Innsbruck, Wien, Bozen 2009).

I9 Some of the crucial publications include Irving Sandler, Abstract Expressionism: The Triumph of American Painting (London, 1970); Michael Leja, Reframing Abstract Expressionism: Subjectivity and Painting in the I940s (New Haven, I997); Katy Siegel, Since '45: America and the Making of Contemporary Art (London, 20I I).

20 Terry Smith has described such a development in 'Abstraction and Ideology: Contestation in Cold War Art Criticism', Okwui Enwezor, Katy Siegel and Ulrich Wilmes (eds), Postwar: Art Between the Pacific and the Atlantic, 1945-I965 (Munich, London, New York, 2016).

2I Hans Betling, Die Deutschen und ihre Kunst: Ein schwieriges Erbe (München, I992) 7.

22 As Enwezor points out, the details of the name change remain unclear: Postwar Art, 23.

23 'Man fragte lieber danach, was Kunst sei als nach deutscher Kunst zu fragen. Die Epochen waren für diese Fragestellung wichtiger als die Länder'; Belting, Die Deutschen und Ihre Kunst, 8. The first documenta exhibition in Kassel in 1955 did not focus on new creations of international contemporary artists. Rather, it followed the agenda of recovering substantial works, which had been lost or plundered. Thus, this exhibit focused on German art in the international context and was conceived as 
a retrospective. Hans Belting explains that the Americans first remained in the background: Art History after Modernism, 37.

24 The exhibition took place at Haus der Kunst from I4 October 20 I 6 until 26 March 2017.

25 The German art museum in Munich became a space for establishing a military officers' club and the site for re-education events including exhibitions on international children's and young people's literature or shows that highlighted those kind of artworks the Nazis had labelled 'degenerate'.

26 Jennifer McComas, 'Reconstrucing Cold War Cultural Diplomacy Exhibitions: The Case of Advancing American Art' Stedelijk Studies 2 (20I5); https://stedelijkstudies.com/journal/reconstructing-cold-warcultural-diplomacy-exhibitions/ (accessed 3 July 20 I9).

27 Quoted in Goldstein, Capturing the German Eye, 84

28 Ibid., 86.

29 Ibid., 87.

30 McComas, 'Reconstructing Cold War cultural Diplomacy Exhibitions'. https://stedelijkstudies.com/journal/reconstructing-cold-war-culturaldiplomacy-exhibitions/ (accessed 3 July 20I9).

3I See the exhibition catalogue edited by Margaret Lynne Ausfeld and Virginia M. Mecklenburg, Advancing American Art: Politics and Aesthetics in the State Department Exhibition, I946-I948 (Montgomery, I984). Also Taylor D. Littleton and Maltby Sykes, Advancing American Art: Painting, Politics, and Cultural Confrontation at Mid-Century (Tuscaloosa, I999).

32 'Exposing the Bunk of So-Called Modern Art', New York Journal-American (3 December I946); quoted in Ausfeld and Mecklenburg, Advancing American Art, I9.

33 Ibid., I9.

34 Ibid.

35 Quoted in Dennis Harper, 'Advancing American Art: LeRoy Davidson's "Blind Date with Destiny", Dennis Harper, Mark Andrew White and Paul Manoguerra (eds), Art Interrupted: Advancing American Art and the Politics of Cultural Diplomacy (Athens, 20I2), unpaginated; https:// stedelijkstudies.com/journal/reconstructing-cold-war-cultural-diplomacyexhibitions/ (accessed I4 Sep. 20I9).

36 Quoted in Taylor D. Littleton and Maltby Sykes (eds.), Advancing American Art: Painting, Politics, and Cultural Confrontation at Midcentury (Tuscaloosa, 2005) 45 . 
37 Quoted in Goldstein, Capturing the German Eye, 80.

38 Catherine Dossin, The Rise and Fall of American Art, I940s-I980s: A Geopolitics of Western Art, I940s-I980s. A Geopolitics of Western Art Worlds (Farnham, 20I5) 40.

39 See David Craven, Abstract Expressionism as Cultural Critique. Dissent during the McCarthy Period (Cambridge, I990) 20.

40 What has been described as a grassroots phenomenon turns out to be a series of overt and covert operations after I945 led by a small group of American cultural officers and German artists creating political and personal networks to form cultural associations, subsidize artists and art prizes, as well as sponsoring exhibits and publications. See Goldstein, Capturing the German Eye, 89.

4I Sigrid Faltin, Die Baroness und das Guggenheim: Hilla von Rebay - Eine Deutsche Künstlerin in New York (Konstanz, 2014) 225-7.

42 Many painters had been trained in the tradition of European late modernism and were re-introduced to German artists after the end of World War II. As Sigrid Faltin notes, many artists who had found an exile in the US are now perceived as art of the occupation force. Ibid., 226.

43 Goldstein, Capturing the German Eye, 99.

44 Quoted in ibid., 99.

45 'Etwas New York in Karlsruhe', Der Spiegel I7 (24 April I948) 2 I.

46 The German original reads: 'Der Gang durch die Ausstellung ihrer neuen Bilder war den Bremer ein Trost. Sie wussten ja schon, wenn gleich nicht genau und im Einzelnen, dass ihre Kunsthalle im Kriege Verluste gehabt hatte. Sie nahmen die Liste der verlorenen Kostbarkeiten mit hanseatischer Fassung auf'; Der Spiegel I7 (24 April I948) 2 I .

47 Ibid., 2 I.

48 The German original reads: 'Die Betrachter in Karlsruhe sagten nur selten "Ja" zum "Non-Objective Painting". In New York wird für diese Kunst ein eigens konstruiertes Museum gebaut, mit Luftregelung und Personenaufzügen statt Treppen'; ibid., 2 I .

49 Anna J. Merritt and Richard L. Merritt, Public Opinion in Occupied Germany. The OMGUS Surveys, I945-I949 (Londoni979) 296. See also Frank Mehring, 'A Memory Goes to Work': The Visual Promise of the Marshall Plan in West-Germany', Jennifer Kapczynski and Caroline Kita (eds.), The Arts of Democratization (Ann Arbor 20I9), forthcoming.

50 Merritt and Merritt, Public Opinion in Occupied Germany, 2 I 7. 
5I See in this context, Axel Lehmann, Der Marshall-Plan und das neue Deutschland. Die Folgen amerikanischer Besatzungspolitik in den Westzonen (Münster, New York, München, Berlin 2000) I72-3.

52 See in this context Frank Mehring, "The Promises of "Young Europe": Cultural Diplomacy, Reeducation, and Youth Culture in the Films of the Marshall Plan', Katharina Gerund and Heike Paul (eds), Die amerikanische Reeducation-Politik nach I945. Interdisziplinäre Perspektiven auf “America's Germany” (Bielefeld, 20 I5).

53 Faltin, Die Baroness und das Guggenheim, 245.

54 Rebay writes in a letter to the architect Frank Lloyd Write, dated I4 February I948, that finally the museum will be realized the way she, her husband and Wright had conceived it: 'all has now culminated exactly as we originally had planned it'; Faltin, Die Baroness und das Guggenheim, 255 .

55 Russia finally returned the watercolour to the Kunsthalle Bremen in 2000.

56 By the time of publication, the exact date of the painting could not be retrieved.

57 See Eduard Beaucamp, 'Spätheimkehrer Dürer', Frankfurter Allgemeine Zeitung (I2 March 2003); https://www.faz.net/aktuell/feuilleton/ beutekunst-spaetheimkehrer-duerer-I92878.html (accessed 3 July 20I9).

58 See Faltin, Die Baroness und das Guggenheim, 225.

59 'Die neue malerische Gesinnung treibt die Entwicklung weiter, die Hilla Rebay heute genau so emphatisch vertritt wie der i9i6 gefallene Franz Marc: Heute hat - die Malkunst die Führung in neue Reiche geistiger Vision übernommen. Diese Maler sind Propheten einer neuen Ära', Die Zeit (8 April I948); https://www.zeit.de/I948/I5/gegenstandslose-malerei (accessed 3 July 20I9).

60 Ibid; the emphasis is mine.

6I See Faltin, Die Baroness und das Guggenheim, 23 I.

62 Solomon R. Guggenheim Museum Archives, Box 88, folder 29.

63 Letter from Peter Engel to Hilla Rebay (I6 September I950), Solomon R. Guggenheim Museum Archives, Box 88, folder 29.

64 As mentioned in the beginning of this article, recent exhibitions devoted to remapping art in Europe such as Facing the Future: Art in Europe 1945I968 (2017) and Postwar: Art Between the Pacific and the Atlantic, I9451965 (2017) with a particular emphasis on multi-perspectivity emerge to a certain degree as the latest signposts of and responses to the American re-education programme. 


\section{About the Author}

Frank Mehring is professor of American Studies at Radboud University, Nijmegen. His research focuses on cultural transfer, immigration, music and intermediality. In 20I2, he received the biennial Rob Kroes Award, for his monograph The Democratic Gap: Transcultural Confrontations of German Immigrants and the Promise of American Democracy (2014). Other publications include Sphere Melodies on American avant-garde music (2003), a biography on Karl/ Charles Follen (2004), Transcultural Spaces: Challenges of Urbanity, Ecology, and Environment (2010), and The Soundtrack of Liberation (20I5). Mehring is a board member of the European Association of American Studies and the Netherlands American Studies Association, the International Committee of the American Studies Association and part of the steering committee of the European Digital Studies Network. He co-curated exhibitions on the artist Winold Reiss, the Marshall Plan and Liberation Songs in New York, Nijmegen and The Hague. E-mail: f.mehring@let.ru.nl 